\title{
PENGARUH UKURAN KOPERASI, JENIS KOPERASI SERTA PENGALAMAN KEPENGURUSAN MANAJEMEN TERHADAP KUALITAS SISTEM PENGENDALIAN INTERN PADA KOPERASI DI KABUPATEN TABANAN
}

\author{
Ni Made Intan Priliandani \\ Fakultas Ekonomi Universitas Warmadewa \\ intanpriliandani88@gmail.com \\ Ni Made Rai Juniariani \\ Fakultas Ekonomi Universitas Warmadewa \\ raijuniari@gmail.com \\ Ni Putu Sri Mariyatni \\ Fakultas Ekonomi Universitas Warmadewa \\ srimariyatni17@gmail.com
}

\begin{abstract}
Cooperatives are a different organization with other businesses, such as BUMN and BUMD or government organizations. The uniqueness of cooperatives is that cooperatives are business units that have multiple identities in which each cooperative member is the owner and user of cooperative services. In order to be able to compete with other financial institutions, the cooperative must be able to determine a policy and strategy that must be developed and improved. One policy that can be taken to assist the development of cooperatives is the effectiveness of management control systems. Internal control is an activity that is influenced by the organization, coordinated methods and provisions to maintain organizational wealth, check accuracy, and reliability of accounting data, to improve business efficiency and encourage compliance with company regulations. The cooperative internal control system is influenced by several factors, namely the size of the cooperative, the type of cooperative, and the management experience of management. This study has the purpose of 1) whether the size of the cooperative influences the quality of the internal control system in cooperatives in Tabanan Regency. 2) whether the type of cooperative influences the quality of the internal control system in cooperatives in Tabanan Regency. 3) whether the management experience affects the quality of the internal control system in cooperatives in Tabanan Regency. This study uses primary data in the form of answers to questionnaires from supervisors and directors of cooperatives in Tabanan district. The sampling technique in this study is purposive sampling technique so that the sample in this study amounted to 35 cooperatives. The analysis technique used to answer the hypothesis is multiple linear regression. The
\end{abstract}


Ni Made Intan P., Ni Made Rai I., \& Ni Putu Sri M. : Pengaruh Ukuran Koperasi, Jenis Koperasi ...

results of the study show that 1 ) the size of the cooperative has a positive effect on the quality of the internal control system. 2) types of cooperatives have a positive effect on the quality of the internal control system. 3) management management experience has a positive effect on the quality of the internal control system.

Keywords: Cooperative Size, Cooperative Type, Management Experience, Quality of Internal Control System

\begin{abstract}
ABSTRAK
Koperasi merupakan suatu organisasi yang berbeda dengann usaha lainnya, seperti BUMN dan BUMD atau organisasi pemerintah. Keunikan yang dimiliki koperasi adalah koperasi merupakan unit usaha yang memiliki identitas ganda yang mana setiap anggota koperasi merupakan pemilik sekaligus pengguna jasa koperasi. Agar mampu bersaing dengan lembaga keuangan lainnya, maka koperasi harus dapat menentukan suatu kebijakan dan strategi yang harus dikembangkan dan ditingkatkan. Salah satu kebijakan yang dapat diambil untuk membantu pengembangan koperasi adalah dengan efektifitas sistem pengendalian manajemen. Pengendalian intern adalah suatu aktivitas yang dipengaruhi oleh organisasi, metode dan ketentuan yang terkoordinasi untuk menjaga kekayaan organisasi, memeriksa ketelitian, dan kehandalan data akuntansi, untuk meningkatkan efisiensi usaha dan mendorong ditaatinya peraturan perusahaan. Sistem pengendalian intern koperasi dipengaruhi oleh beberapa faktor, yaitu ukuran koperasi, jenis koperasi, serta pengalaman kepengurusan manajemen. Penelitian ini memiliki tujuan 1) apakah ukuran koperasi berpengaruh terhadap kualitas sistem pengendalian intern pada koperasi-koperasi di Kabupaten Tabanan. 2) apakah jenis koperasi berpengaruh terhadap kualitas sistem pengendalian intern pada koperasi-koperasi di Kabupaten Tabanan. 3) apakah pengalaman kepengurusan manajemen berpengaruh terhadap kualitas sistem pengendalian intern pada koperasi-koperasi di Kabupaten Tabanan. Penelitian ini menggunakan data primer yaitu berupa jawaban kuesioner dari pengawas dan direktur koperasi di kabupaten Tabanan. Teknik sampling dalam penelitian ini adalah teknik purposive sampling sehingga sampel dalam penelitian ini berjumlah 35 koperasi. Teknik analisis yang digunakan untuk menjawab hipotesis adalah regresi linear berganda. Hasil penelitian menunjukkan 1) ukuran koperasi berpengaruh positif terhadap kualitas sistem pengendalian intern. 2) jenis koperasi berpengaruh positif terhadap kualitas sistem pengendalian intern. 3) pengalaman kepengurusan manajemen berpengaruh positif terhadap kualitas sistem pengendalian intern.
\end{abstract}


Kata Kunci : Ukuran Koperasi, Jenis Koperasi, Pengalaman Kepengurusan Manjemen, Kualitas Sistem Pengendalian Intern

\section{PENDAHULUAN}

Pertumbuhan ekonomi kerakyatan saat ini di Indonesia belum stabil hal ini berdampak pada kehidupan masyarakat kecil yang semakin memprihatinkan. Hal ini sangat dirasakan oleh masyarakat yang berada pada garis perekonomian menengah ke bawah yaitu masyarakat yang berada di daerah pedesaan. Dalam hai ini, peran koperasi sebagi roda perekonomian nasional serta lembaga yang bergerak dalam ekonomi rakyat sudah dapat dikatakan mengalami perkembangan yang pesat dan dinamis. Pemerintah menetapkan bahwa koperasi berperan penting sebagai salah satu pelaku jalannya perekonomian di Indonesia. Kebijakan pemerintah ini sesuai dengan Undang-Undang dasar 1945 pasal 33 ayat 1 yang menyatakan bahwa perekonomian disusun sebagai usaha bersama berdasarkan asas kekeluargaan.

Dalam Undang-undang No 17 pasal 1 ayat 1 tahun 2012 menyebutkan bahwa Koperasi adalah badan hokum yang didirikan oleh orang perseorangan atau badan hukum yang didirikan oleh orang perseorangan atau badan hukum Koperasi, dengan pemisahan kekayaan para anggotanya sebagai modal untuk 
menjalankan usaha, yang memenuhi aspirasi dan kebutuhan bersama di bidang ekonomi, social, dan budaya sesuai dengan nilai dan prinsip Koperasi. Koperasi adalah salah satu bentuk badan usaha yang didirikan oleh orangorang tertentu, untuk melaksanakan kegiatan-kegiatan tertentu, berdasarkan ketentuan dan tujuan tertentu. (Revrisond, 2000). Pengertian Koperasi secara umum memiliki pengertian bahwa koperasi adalah suatu perkumpulan orang secara sukarela berjuang bersama-sama untuk meningkatkan kesejahteraan ekonomi mereka melalui pembentukan suatu badan usaha yang dikelola secara demokratis.

Koperasi merupakan organisasi yang berbeda dengan badan usaha lainnya, seperti BUMN dan BUMD atau organisasi pemerintah. Keunikan yang dimiliki koperasi adalah koperasi merupakan unit usaha yang memiliki identitas ganda yang mana setiap anggota koperasi merupakan pemilik sekaligus pengguna jasa koperasi. Disamping itu dalam hal pencarian dan dan perolehan dana, koperasi berpegang pada prinsip swadaya artinya diupayakan modal berasal dari kemampuan sendiri yang ada dalam koperasi. Umumnya koperasi dikendalikan secara bersama oleh seluruh anggotanya, dimana setiap anggotanya memilikihak suar yang sama dalam setiap keputusan yang diambil koperasi. Pembagian keuntungan koperasi (Sisa Hasil Usaha) biasanya dihitung berdasarkan andil anggota tersebut dalam koperasi. 
Dalam perkembangan permasalahan yang dihadapi oleh koperasi, misalnya dalam segi pembiayaan dan permodalan. Permasalahan yang lain adalah adanya keterbatasan sumber daya manusia, sarana dan prasarana yang memadai yang dimiliki oleh koperasi. Agar mampu bersaing dengan lembaga keuangan lainnya maka koperasi harus dapat menentukan suatu kebijakan dan strategi yang harus dikembangkan dan ditingkatkan. Salah satu kebijakan yang dapat diambil untuk membantu pengembangan koperasi adalah dengan meningkatkan efektifitas sistem pengendalian manajemen.

Mulyadi (2010) menyatakan bahwa sistem pengendalian intern adalah suatu sistem yang meliputi struktur organisasi, metode, dan ukuran-ukuran yang dikoordinasikan untuk menjaga kekayaan organisasi, mengecek ketelitian dan keandalan data akuntansi, mendorong efisiensi dan mendorong dipatuhinya kebijakan manajemen. Pengendalian intern adalah kegiatan yang sangat penting dalam pencapaian tujuan perusahaan dan pengendalian intern membantu mendeteksi dan mencegah berbagai pengaruh lingkungan terhadap sistem. Setiap perusahaan termasuk koperasi pasti memiliki sistem pengendalian dalam menjalankan usahanya, dimana sistem tersebut disesuaikan dengan keadaan dan kondisi masing-masing perusahaan karena jenis dan bentuk yang berbeda-beda (Palupi, 2011). 
Berdasarkan pengertian di atas maka pengendalian intern adalah suatu aktivitas yang dipengaruhi oleh organisasi, metode dan ketentuan yang terkoordinasi untuk menjaga kekayaan organisasi, memeriksa ketelitian, dan kehandalan data akuntansi, untuk meningkatkan efisiensi usaha dan mendorong ditaatinya peraturan perusahaan. Kebijakan tentang pengendalian intern suatu koperasi telah diatur dalam Peraturan Menteri Negara Koperasi, Usaha Kecil Dan Menengah nomor 21 tahun 2008 yaitu sistem pengendalian internal untuk koperasi, usaha kevil dan menengah merupakan kebijakan dan prosedur yang dijalankan oleh pengawas, pengurus, dan manajemen koperasi untuk mengamankan kekayaan koperasi dan memberikan keyakinan yang memadai tentang keandalan informasi laporan keuangan, kepatuhan terhadap peraturan perundang-undangan dalam menunjang efektifitas dan efisiensi operasi.

Sistem pengendalin intern koperasi dipengaruhi oleh beberapa faktor, misalnya ukuran koperasi, jenis koperasi, serta pengalaman kepengurusan manajemen. Untuk menentukan besar kecilnya suatu koperasi dapat dilihat dari jumlah omzet per tahunnya. Keputusan Mentri Koperasi Nomor 351/KEP/M/XII/1998 menyatakan bahwa ukuran koperasi diklasifikan menjadi tiga golongan yaitu : 
1. Koperasi Besar adalah koperasi yang mempuyai omzet diatas RP. 1.000.000.000 dalam satu tahun.

2. Koperasi Menengah adalah koperasi yang mempunyai omzet antara Rp. 500.000.000 samapai dengan 1.000.000.000 dalam satu tahun.

3. Koperasi Kecil adalah koperasi yang mempunyai omzet kurang dari Rp. 500.000.000 dalam satu tahun.

Palupi, 2011 menyatakan bahwa semakin besar ukuran koperasi maka semakin sulit dalam mengawasi kegiatan usahanya, dengan demikian maka semakin besar ukuran koperasi maka kualitas sistem pengendalian intern umu, penerimaan kas, pengeluaran kas, dan praktik rekonsiliasi yang digunakan juga akan semakin baik dan terkontrol.

Faktor lain yang mempengaruhi sistem pengendalian intern dalam suatu koperasi adalah jenis koperasinya. Jenis koperasi dapat dibedakan berdasarkan kesamaan kegiatan koperasi dan kepentingan ekonomi anggotanya. UUD Nomor 17 tahun 2012 menyebutkan bahwa jenis koperasi terdiri dari 4 jenis, sedangkan dalam UUD Nomor 25 tahun 1992 terdapat 5 jenis koperasi.

Faktor yang lain yang dapat mempengaruhi sistem pengendalian intern suatu koperasi adalah pengalaman kepengurusan manjemen. Pengalaman kepengurusan manajemen adalah proses pembentukan pengetahuan dan 
ketrampilan tentang metode suatu pekerjaan karena keterlibatan karyawan dalam pelaksanaan tugas pekerjaan. Manulang (1984) dalam Rinawati (2007).

Penelitian mengenail pengendalian intern dalam koperasi masih belum banyak dilakukan, kebanyakan penelitian mengenai pengendalian intern dilakukan di perusahaan manufaktur atau BUMN dan BUMD. Penelitian di Koperasi jarang dilakukan karena koperasi dianggap masih usaha kecil yang tidak memerlukan pengendalian intern, tetapi hal itu sudang berbanding terbalik sekarang koperasi banyak diminati oleh masyarakat karena fungsinya yang data memberikan pinjaman, simpanan, jasa pembayaran lainnya, serta transfer uang bagi masyarakat, masih banyak juga fungsi-fungsi koperasi yang lainnya yang tentu saja dapat menguntungkan bagi masyarakat serta anggotanya.

Penelitian dilakukan pada koperasi-koperasi di wilayah kabupaten Tabanan hal ini disebabkan karena wilayah Tabanan merrupakan salah satu wilayah di Propinsi Bali yang memiliki hasil pertanian dan perkebunan yang cukup tinggi, hal ini menyebabkan kepercayaan penduduk Kabupaten Tabanan terhadap Koperasi masih tinggi sebagai tempat dalam meminjam dan menyimpan uang.

Berdasarkan latar belakang di atas, maka yang menjadi pokok permasalahan dalam penelitian ini adalah? 
a. Apakah ukuran koperasi berpengaruh terhadap kualitas sistem pengendalian intern pada koperasi-koperasi di Kabupaten Tabanan?

b. Apakah jenis koperasi berpengaruh terhadap kualitas pengendalian intern pada koperasi-koperasi di Kabupaten Tabanan?

c. Apakah pengalaman kepengurusan manajemen berpengaruh terhadap kualitas pengendalian intern pada koperasi-koperasi di Kabupaten Tabanan?

\section{KAJIAN PUSTAKA}

\section{Teori Keagenan (Agensi Theory)}

Menurut Jensen dan Meckling (1976) teori agensi merupakan konsep yang menjelaskan hubungan kontraktual antara agent dan principal. Hubungan kontraktual merupakan hubungan dimana satu atau lebih principal menyewakan orang lain untuk melakukan beberapa jasa untuk kepentingan mereka yaitu memberikan perintah kepada agen, dalam hal ini yaitu pemegang saham, sedangkan yang disebut dengan agen adalah pihak yang mengerjakan perintah dari principal, yaitu manajemen yang mengelola perusahaan.

Teori keagenan memiliki tujuan yaitu untuk menjelaskan bagaimana pihak-pihak yang melakukan hubungan kontrak dapat mendesain kontrak yang 
tujuannya untuk meminimalisir biaya sebagai dampak adanya informasi yang tidak sismetris dan kondisi ketidakpastian. Sehingga teori keagenan ini memiliki unsur-unsur yang membantu terlaksananya koperasi ini dengan bersumber pada pemegang saham, pemberi pinjaman dan sebagainya.

Sistem pengendalian intern berfungsi untuk mengawasi tugas dan fungsi masing-masing unit bagian., sehingga setiap unit bagian memiliki tugas dan wewenangnya masing-masing. Koperasi memiliki perangkat organisasi yang terdiri dari rapat anggota, pengurus, pengawas. Rapat anggota merupakan pemegang kekuasaan tertinggi dalam koperasi. Dalam hal ini pengendalian intern sangat diperlukan untuk mengawasi tugas dan tanggung jawab setiap fungsi, sehingga dapat mencegah penyalahgunaan oleh pihakpihak yang tidak berwenang atas tugas tiap fungsi.

Berdasarkan teori keagenan tersebut maka sistem pengendalian intern dirasa sangat penting bagi seluruh organisasi terutama koperasi untuk menghindari konflik kepentingan yang terjadi antara principaldan agent.

\section{Pengertian Koperasi}

UUD nomor 17 tahun 2012 tentang perkoperasian menyatakan bahwa koperasi adalah badan hukum yang didirikan oleh orang perseorangan atau badan hukum koperasi, dengan pemisahan kekayaan para anggotanya sebagai modal untuk menjalankan usaha yang memenuhi aspirasi dan kebutuhan 
bersama dibidang ekonomi, social, dan budaya sesuai dengan nilai dan prinsip koperasi.

Hanel (1989) menyatakan bahwa koperasi adalah organisasi otonom yang berada dalam lingkungan social ekonomi, yang memungkinkan setiap individu dan setiap kelompok orang untuk merumuskan tujuantujuannyasecara otonom dan mewujudkan tujuan-tujuan itu melalui aktivitas ekonomi yang dilaksanakan secara bersam-sama. Jadi koperasi adalah badan usaha yang beranggotakan orang-orang atau badan hukum koperasi dengan melandaskan kegiatannya berdasarkan prinsip koperasi sekaligus sebagai gerakan ekonomi rakyat yang berdasarkan azas kekeluargaan dan bertujuan untuk mensejahterakan anggotanya.

\section{Ukuran Koperasi}

UU No 20Tahun 2008 mengenai himpunan peraturan tentang perbankkan, perkoperasian, usaha mikro, kecil dan menengah menjelaskan bahwa ukuran koperasi dapat dilihat berdasarkan omzet pertahun yang dimuat dalam laporan keuangan perkembangan usaha. Berdasarkan volume usaha atauomzetnya ukuran koperasi diklasifikasikan menjadi tiga golongan, yaitu koperasi besar, menengah, dan kecil sesuai KeputusanMenteri Koperasi Nomor 351/KEP/M/XII/1998: 
1. Koperasi besar mempunyai omzet diatas Rp. 1.000 .000 .000 dalam satu tahun.

2. Koperasi menengah mempunyai omzet antara Rp. 500.000 .000 sampai dengan Rp. 1.000.000.000 dalam satu tahun.

3. Koperasi kecil mempunyai omzet kurang dari Rp. 500.000.000dalam satu tahun.

\section{Jenis Koperasi}

UUD Nomor 17 tahun 2012 tentang Perkoperasian Pasal 82, jenis koperasi didasarkan pada kesamaan kegiatan usaha dan/atau kepentingan ekonomi. Jenis koperasi terdiri dari empat jenis, yaitu:

1. Koperasi konsumen

Koperasi konsumen adalah koperasi yang menyelenggarakan kegiatan usaha pelayanan dibidang penyediaan barang kebutuhan anggota dan non anggota.

2. Koperasi Produsen

Koperasi produsen adalah koperasi yang menyelenggarakan kegiatan usaha pelayanan dibidang pengadaan sarana produksi dan pemasaran produksi yang dihasilkan anggota kepada anggota dan non anggota.

3. Koperasi Jasa 
Koperasi Jasa adalah koperasi yang menyelenggaran kegiatan usaha pelayanan jasa non simpan pinjam yang diperlukan oleh anggota dan non anggota.

4. Koperasi Simpan Pinjam

Koperasi simpan pinjam adalah koperasi yang menjalankan usaha simpan pinjam sebagai salah satu usaha yang melayani anggota.

UUD Nomor 17 tentang Perkoperasian dibatalkan pada hari rabu tanggal 28 mei 2014 oleh MK dan kembali ke UUD no 25 than 1992 tentang perkoperasian. Dalam UUD nomor 25 tahun 1992 tentang perkoperasian jenis koperasi dibedakan menjadi lima yaitu:

1. Koperasi Simpan Pinjam

Koperasi simpan pinjam adalam koperasi yang bergerak dibidang simpanan dan pinjaman sebagai salah satu usaha yang melayani anggotanya.

2. Koperasi Konsumen

Koperasi konsumen adalah koperasi yang beranggotakan para konsumen dengan menjalankan kegiatan jual beli menjual barang konsumsi

3. Koperasi Produsen

Koperasi produsen adalah koperasi yang beranggotakan para pengusaha kecil dengan menjalankan kegiatan pengadaan bahan baku dan penolong untuk anggotanya. 
4. Koperasi Pemasaran

Koperasi pemasaran adalah koperasi yang menjalankan kegiatan penjualan produk/jasa koperasi atau anggotanya.

5. Koperasi Jasa

Koperasi jasa adalah koperasi yang bergerak dibidang usaha jasa lainnya dan koperasi yang menyelengggarakan kegiatan usaha pelayanan jasa non sismpan pinjam yang diperlukan oleh anggota dan non anggota.

\section{Pengalaman Kepengurusan Manajemen}

Pengalaman kerja menurut Manulang (1984) dalam Rinawati (2007) menyatakan pengalaman kerja sebagai proses pembentukan pengetahuan dan ketrampilan tentang motode suatu pekerjaan karena keterlibatan karyawan tersebut dalam pelaksanaan tugas pekerjaaan. UUD Nomor 25 tahun 1992 tentang perkoperasian dijelaskan tentang kedudukan pengurus sebagai pemegang kuasa rapat anggota dan memiliki tugas dan wewenang. Sudarsono (2005) menyebutkan bahwa pengalaman-pengalaman tertentu sangat berguna dalam praktik mengurus koperasi. Pengalaman kerja manajemen akan mendukung ketrampilan dan kecepatan dalam menyelesaikan tugas-tugas manajemen sehingga tingkat kesalahan akan berkurang.

Indrawan (2009) pengalaman kerja adalah keahlian atau kemampuan yang dimiliki seseorang pada suatu bidang pekerjaan yang diperoleh dengan 
belajar dalam suatu kurun waktu tertentu yang tentunya dilihat dari kemampuan intelegasi baik pengalaman yang berasal dari luar perusahaan maupun dari dalam perusahaan.

\section{Sistem Pengendalian Intern}

Mulyadi (2002) sistem pengendalian intern adalah suatu sisitem yang meliputi struktur organisasi, metode dan ukuran-ukuran yang dikoordinasikan untuk menjaga kekayaan organisasi, mengecek ketelitian dan keandalan data akuntansi, mendorong efisiensi dan mendorong dipatuhinya kebijakan manajemen.

coso (Committee of Sponsoring Organization) menedefinisikan pengendalian intern sebagai proses, dipengaruhinya oleh dewan komisaris, manajemen dan personel perusahaaan, yang dirancang untuk menyediakan jaminan yang dapat dipercaya untuk mencapai tujuan perusahaan, yang digolongkan menjadi 3, yaitu:

1. Keandalan Laporan Keuangan

Keandalan laporan keuangan adalah hasil akhir dari proses kegiatan atau suatu ringkasan dari transaksi keuangan. Laporan keuangan disusun untuk memeberikan informasi tentang posisi harta, untung dan modal. 
2. Efektivitas dan efisiensi operasi

Efektivitas dan efisiensi adalah sesuatu yang mampu mencapai target dengan menggunakan biaya yang sama untuk menghasilkan hasil yang lebih besar.

3. Kepatuhan terhadap hukum dan peraturan yang berlaku

Kepatuhan terhadap hukum dan peraturan yangberlaku adalah sesuatu yang menunjukkan perilaku yang sesuai dengan apa yang diharuskan oleh peraturan perundang-undangan yang berlaku.

Dapat disimpilkan bahwa pengendalian intern merupakan suatu sisitem yang terdiri dari berbagai unsur dengan tujuan untuk melindungi harta benda dan seberapa jauh dapat dipercaya data akuntansinya, mendorong efisiensioperasi dan menunjang dipatuhinya kebijaksanaan.

Halim (2005) menyatakan empat tujuan pokok pengendalian intern, adalah:

1. Menjaga kekayaan dan catatan organisasi.

2. Mengecek ketelitian dan keandalan data akuntansi

3. Mendorong efisiensi

4. Mendorong dipatuhinya kebijakan manajemen 
Tujuan yang pertama dan kedua dapat dipenuhi dengan pengendalian akuntansi yang baik, sedangkan tujuan yang ketiga dan keempat dapat dipenuhi dengan pengendalian administrasi yang baik.

COSO menyatakan ada lima komponen pengendalian intern yang saling berhubungan yaitu:

\section{Lingkungan Pengendalian}

Lingkungan pengendalian mencakup standar, proses dan struktur yang menjadi landasan terselenggaranya pengendalian internal di dalam organisasi secara menyeluruh. Lingkungan Pengendalian tercermin dari suasana dan kesan yang diciptakan dewan komisaris dan manajemen puncak mengenai pentingnya pengendalian internal dan standar perilaku yang diharapkan. Manajemen mempertegas harapan atau ekspektasi itu pada berbagai tingkatan organisasi. Sub-komponen lingkungan pengendalian mencakup integritas dan nilai etika yang dianut organisasi, parameter-parameter yang menjadikan dewan komisaris mampu melaksanakan tanggung jawab tatat kelola, struktur organisasi serta pembagian wewenang dan tanggung jawab, proses untuk menarik, mengembangkan, dan mempertahankan individu yang kompeten serta kejelasan ukuran kinerja, insentif, dan imbalan untuk mendorong akuntabilitas kinerja. Lingkungan pengendalian berdampak luas terhadap 
sistem pengendalian internal secara keseluruhan. Selain itu lingkungan pengendalian dari orang-orang yang ada didalam organisasi tersebut. Lingkungan pengendalian menjadi dasar bagi komponen yang lain dan menyediakan disiplin serta struktur.

2. Perhitungan Risiko

Perhitungan risiko untuk tujuan pelaporan keuangan adalah identifikasi, analitis, dan pengelolaan risiko suatu perusahaan berkenaan dengan penyusunan laporan keuangan yang disajikan secara wajar sesuai dengan prinsip akuntansi berlaku umum. Perhitungan risiko oleh manajemen harus mencakup pertimbangan khusus untuk risiko yang bias muncul akibat perubahan-perubahan yang terjadi, seperti adanya bidang usaha baru dengan transaksi-transaksi baru yang prosedur akuntansinya belum begitu dipahami, perubahan standar akuntansi, perubahan undangundang, revisi atas sistem atau digunakannya teknologi baru dalam pengelolaan informasi, perubahan cepat yang terjadi pada perusahaan sehingga pengolahan informasi dan fungsi pelaporan menjadi kewalahan, dan perubahan personil yang terlibat dalam pengolahan informasi dan fungsi pelaporan. 


\section{Informasi dan Komunikasi}

Sistem informasi yang berhubungan dengan tujuan pelaporan keuangan, yang mencakup sistem akuntansi, terdiri dari metode dan catatan-catatan yang digunakan untuk mengidentifikasi, menggabungkan, menganalisa, menggolongkan, mencatat, dan melaporkan transaksi perusahaan termasuk kejadian dan kondisi serta menyelenggaran pertanggungjawaban atas aktiva dan kewajiban yang bersangkuta.

Entitas memerlukan informasi demi terselenggarannya tanggung jawab pengendalian internal yang mendukung pencapaian tujuan. Manajemen harus memperoleh, menghasilkan, dan menggunakan informasi yang relevan dan berkualitas, baik yang berasal dari sumber internal maupun eksternal, untuk mendukung komponen-komponen pengendalian internal lainnya berfungsi sebagaimana mestinya. Komunikasi sebagaimana yang dimaksud dalam kerangka pengendalian internal cOSO adalah proses berkelanjutan unttuk memperoleh, membagikan, dan menyediakan informasi. Komunikasi internal harus menjadi sarana diseminasi informasi di dalam organisasi, baik dari atas ke bawah, dari bawah ke atas, maupun lintas fungsi. 
4. Aktivitas Pengendalian

Aktivitas pengendalian adalah kebijakan dan prosedur yang membantu meyakinkan bahwa perintah manajemen telah dijalankan. Kebijakan dan prosedut tersebut membantu meyakinkan bahwa tindakan yang diperlukan telah dijalankan untuk mencapai tujuan perusahaan. Aktivitas pengendalian

Aktivitas-aktivitas pengendalian mencakup tindakan-tindakan yang ditetapkan melalui satu set kebijakan dan prosedur (misalnya prosedur operasi standar atau SOP) untukmembantu memastikan dilaksanakannya arahan manajemen dalam rangka meminimalkan risiko atas pencapaian tujuan. Aktivitas-aktivitas pengendalian dilaksanakan pada semua tingkatan entitas, pada berbagai tahap proses bisnis, dan dalam setting atau konteks teknologi yang digunakan. Aktivitas pengendalian ada yang bersifat preventif atau detektif, Aktivitas pengendalian juga bias manual atau otomatis, contohnya aktivitas otorisasi dan persetujuan, verifikasi, rekonsiliasi, dan evaluasi kinerja. Pembagian tugas harus erat terkait dengan proses pemilihan dan pengembangan aktivitas pengendalian. Jika pembagian tugas dianggap tidak praktis, manajemen harus memilih dan mengembangkan alternatif aktivitas pengendalian. 


\section{Pemantauan}

Pemantauan adalah suatu proses penilaian aktivitas kualitas kinerja struktur penegndalian intern sepanjang masa. Hal itu menyangkut penilaian tentang rancangan dan pelaksanaan operasi pengendalian oleh orang yang tepat untuk setiap periode waktu tertentu, untuk menentukan bahwa SPI telah berjalan sesuai dengan yang dikehendaki dan bahwa modifikasi yang diperlukan karena adanya perubahan-perubahan kondisi telah dilakukan. Pemantauan secara terus menerus terhadap aktivitas dibangun kedalam aktivitas pengelolaan dan supervise yang regular. Manjer penjualan, pembelian, dan produksi pada tingkat divisi dan korporat berhubungan dengan operasi dan dapat mengajukan pertanyaan atas laporan yang menyimpang secara signifikan dari pengetahuan mereka tentang koperasi.

Sistem pengendalian intern merupakan kebijakan dan prosedur yang dijalankan oleh pengawas, pengurus dan manajemen koperasi untuk mengamankan kekayaan koperasi dan memberikan keyakinan yang memadai tentang keandalan informasi laporan pertanggung jawaban keuangan, kepatuhan terhadap peraturan perundang-undangan dalam menunjang efektivitas dan efisiensi operasi. Untuk menunjang pelaksanaan pengendalian intern pada koperasi maka Menteri Negara Koperasi dan Usaha Kecil dan Menengah mengeluarkan Peraturan Menteri nomor 21 
tahun 2008 tentang pedoman pengawasan koperasi simpan pinjam dan unit simpan pinjam koperasi. Objek pemeriksaan yang tertulis dalam peraturan ini meliputi lima aspek, yaitu aspek organisasi, aspek pengelolaan, aspek keuangan, produk dan layanan, serta aspek pembinaan anggota, pengurus, pengawas, dan pengelola.

Sistem pengendalian intern dalam SAK-ETAP, SAK ETAP dimaksudkan untuk digunakan oleh Entitas Tanpa Akuntabilitas Publik, yaitu entitas yang tidak memiliki akuntabilitas public signifikan dan menerbitkan laporan keuangan untuk tujuan umum bagi pengguna eksternal. Diharapkan dengan adanya SAK ETAP, perusahaan kecil, menengah mampu menyusun laporan keuangannyauntuk mendapatkan dana pengembangan usaha.Pengguna SAK ETAP lebih mudah dalam implementasinya, tetapi tetap memberikan informasi yang handal dalam penyajian laporan keuangan. Entitas yang menggunakan SAK ETAP harus secara eksplisit menyatakan secara penuh atas kepatuhan terhadap SAK ETAP dalam catatan laporan keuangan.

Entitas diwajibkan untuk menyajikan laporan keuangan minimal satu kali dalam setahun. Pengendalian intern suatu entitas diperlukan untuk menjaga tingkat kepatuhan entitas serta penyusunan laporan keuangan yang sesuai dengan peraturan yang terdapat didalam SAK ETAP. 


\section{METODE PENELITIAN}

\section{Populasi dan Sampel Penelitian}

Populasi adalah wilayah generalisasi yang terdiri dari objek atau subjek yang mempunyai kualitas dan karakteristik tertentu yang ditetapkan penelitian untuk dipelajari dan kemudian ditarik kesimpulannya (Sugiyono, 2013). Populasi dalam penelitian ini adalah koperasi-koperasi yang ada di wilayah Kabupaten Tabanan. Sampel dalam penelitian ini bersifat kuantitatif yaitu sebagian dari populasi (Sugiyono, 2013). Pengambilan sampel dalam penelitian ini menggunakan tehnik purposive sampling yaitu tehnik pengambilan sampel penelitian dengan beberapa pertimbangan tertentu yang bertujuan agar data yang diperoleh nantinya bisa lebih representative (Sugiyono, 2013). Adapun pertimbangan dalam pengambilan sampel pada penelitian ini adalah:

1. Seluruh Koperasi yang aktif di Kabupaten Tabanan.

2. Koperasi di Kabupaten Tabanan yang telah melakukan RAT (Rapat anggota Tahunan)

3. Koperasi di Kabupaten Tabanan yang telah berdiri lebih dari 1 tahun.

Berdasarkan pertimbangan tersebut maka jumlah sampel dalam penelitian ini terdiri dari 35 koperasi. 


\section{Variabel Operasional dan Pengukuran Variabel}

Variabel yang digunakan dalam penelitian ini adalah variabel independen

$(\mathrm{X})$ dan variabel dependen $(\mathrm{Y})$. Variabel independen terdiri dari ukuran koperasi $(\mathrm{X} 1)$, jenis koperasi $(\mathrm{X} 2)$, pengalaman kepengurusan manajemen $(\mathrm{X} 3)$. Variabel dependennya adalah kualitas sistem pengendalian intern.

1. Variabel Terikat (Dependen)

Variabel terikat merupakan variabel yang dipengaruhi atau yang menjadi akibat, karena adanya variabel bebas (Sugiyono, 2013). Variabel terikat dalam penelitian ini adalah kualitas sistem pengendalian intern. Variabel ini di ukur dengan menggunakan kuisioner yang disebarkan kepada tiap-tiap koperasi. Kuisioner tersebut terdiri dari empat unsur pertanyaan tentang sistem pengendalian intern, yaitu sistem pengendalian untuk umum, sistem pengendalian kas, sistem pengendalian pengeluaran kas, dan sistem pengendalian untuk praktek rekonsiliasi.

2. Variabel Bebas (Independen)

Variabel bebas merupakan variabel yang mempengaruhi atau yang menjadi sebab atau timbulnya variabel terikat (Sugiyono, 2013). Variabel bebas dalam penelitian ini adalah: 
1) Ukuran Koperasi yang dimaksud adalah besar kecilnya koperasi berdasarkan omzet dalam laporan perkembangan usaha selama setahun.

2) Jenis Koperasi berdasarkan UUD nomor 17 tahun 2012 tentang perkoperasian pasal 82 jenis koperasi didasarkan pada kesamaan kegiatan usaha atau kepentingan ekonomi. Jenis koperasi terdiri dari empat jenis, yaitu koperasi konsumen, koperasi produsen, koperasi jasadan koperasi simpan pinjam.

3) Pengalaman kepengurusan Manajemen ditentukan dari lama waktu atau masa kerja kepengurusan manajemen. Lama waktu atau masa kerja di kategorikan menjadi tiga bagian yaitu: jumlah kepengurusan manajemen yang masa kerjanya 0-5 tahun, 5-10 tahun dan diatas 10 tahun. Penilaian untuk lama waktu masa kerja yaitu antara nilai 1 sampai 3, dengan masa kerja 0-5 diberi nilai 1 diatas 5-10 tahun diberi nilai 2, dan masa kerja diatas 10 tahun diberi nilai 3.

\section{Uji Instrumen Penelitian}

Kesungguhan responden dalam menjawab kuisioner merupakan hal yang sangat penting, karena keabsahan (validitas) suatu hasil penelitian sangat ditentukan oleh alat ukur instrumen yang digunakan dan data yang diperoleh. Berdasarkan pertimbangan tersebut, dalam penelitian ini dilakukan pengujian 
apakah instrumen dan data penelitian berupa jawaban responden telah dijawab dengan benar atau tidak. Pengujian tersebut meliputi pengujian validitas dan pengujian reabilitas (keandalan).

\section{Metode Analisis Data}

\section{Uji Asumsi Klasik}

Model regresi yang baik adalah model regresi yang terbebas dari masalah multikolonieritas, heteroskedastisitas, serta masalah normalitas data. Untuk itu maka perlu dilakukan pengujian terhadap model regresi yang akan digunakan pada penelitian. Pengujian tersebut dilakukan dengan uji asumsi klasik sebagai berikut:

1) Uji Normalitas

Uji normalitas data dalam penelitian ini, yaitu dengan menggunakan Uji Kolmogrov smirnov, dalam uji ini pedoman yang digunakan dalam pengambilan keputusan yaitu:

a) Jika nilai signifikan $\leq 0,05$ maka distribusi data tidak normal.

b) Jika nilai signifikan $>0,05$ maka distribusi data normal

2) Uji Multikolonieritas

Multikoleniaritas dapat diketahui dengan cara menganalisis matrik korelasi variabel-variabel independen, dapat dilihat dari Tolerance value dan nilai variance inflation factor (VIF). Kedua ukuran ini menunjukan setiap 
variabel bebas manakah yang yang dijelaskan oleh variabel bebas lainnya. Nilai cutoff yang umum digunakan adalah nilai tolerance 0,10 atau sama dengan VIF diatas 10. Apabila nilai tolerance lebih dari 0,10 atau nilai VIF kurang dari 10 maka dapat dikatakan bahwa tidak terjadi multikolinearitas antar variabel dalam model regresi

3) Uji Heteroskedastisitas

Mendeteksi ada atau tidaknya heteroskedastisitas dapat dilakukan dengan Uji Glejser. Uji Glejser dilakukan dengan cara meregresikan variabel bebas terhadap absolut residual. Model regresi yang tidak mengandung gejala heteroskedastisitas adalah apabila signifikansi variabel bebasnya terhadap nilai absolut residual statistik di atas $a=0,05$ (Ghozali, 2011:108).

\section{Analisis regresi linear berganda}

Analisis regresi linear berganda adalah hubungan secara linear antara dua atau lebih variabel independen $\left(X_{1}, X_{2}, X_{3}\right)$ dengan variabel dependen $(Y)$. Analisi ini untuk mengetahui arah hubungan antara variabel independen dengan variabel dependen apakah masing-masing variabel independen berhubungan positif atau negative dan untuk memprediksi nilai dari variabel dependen apabila nilai varaibel independen mengalami kenaikan atau penurunan. 
Persamaan regresi untuk menguji hipotesis secara keseluruhan pada penelitian ini adalah sebagai berikut:

$$
Y=a+\beta_{1} X_{1}+\beta_{2} X_{2}+\beta_{3} X_{3}+
$$

Keterangan:

$\mathrm{Y} \quad=$ Kualitas Sistem Pengendalian Intern

a $\quad=$ Konstanta

$\beta_{1}-\beta_{3}=$ Koefisien Regresi

$\mathrm{X}_{1}=$ Ukuran Koperasi

$\mathrm{X}_{2}=$ Jenis Koperasi

$\mathrm{X}_{3}=$ Pengalaman Kepengurusan Manajemen

$\varepsilon \quad=$ Faktor lain yang berpengaruh terhadap variabel terikat $(\mathrm{Y})$

\section{HASIL DAN PEMBAHASAN}

\section{Uji Validitas}

Uji validitas digunakan untuk mengukur apakah sah atau valid tidaknya suatu kuisioner. Suatu kuisioner dikatakan valid jika pertanyaan pada kuisioner mampu untuk mengungkapkan sesuatu yang akan diukur oleh kuisioner tersebut. Uji validitas dilihat dari nilai Item-Total Statistics, diketahui bahwa variabel $Y$, memiliki nilai Corrected Item-TOTAL Correlation > 0,3 maka dapat dikatakan kuisioner tersebut valid. Hasil pengujian validitas penelitian ini adalah 


\section{Uji Validitas Penelitian}

\begin{tabular}{|l|r|r|r|r|}
\hline & $\begin{array}{c}\text { Scale Mean } \\
\text { if Item } \\
\text { Deleted }\end{array}$ & $\begin{array}{c}\text { Scale } \\
\text { Variance if } \\
\text { Item Deleted }\end{array}$ & $\begin{array}{c}\text { Corrected } \\
\text { Item-Total } \\
\text { Correlation }\end{array}$ & $\begin{array}{c}\text { Cronbach's } \\
\text { Alpha if Item } \\
\text { Deleted }\end{array}$ \\
\hline Y.1 & 67,4857 & 313,787 &, 860 &, 987 \\
Y.2 & 67,4857 & 311,551 &, 897 &, 987 \\
Y.3 & 67,4857 & 310,022 &, 936 &, 987 \\
Y.4 & 67,3714 & 317,417 &, 854 &, 987 \\
Y.5 & 67,5714 & 312,017 &, 879 &, 987 \\
Y.6 & 67,5714 & 311,076 &, 924 &, 987 \\
Y.7 & 67,3714 & 310,064 &, 937 &, 987 \\
Y.8 & 67,4857 & 310,139 &, 912 &, 987 \\
Y.9 & 67,4000 & 315,188 &, 878 &, 987 \\
Y.10 & 67,5429 & 320,903 &, 779 &, 988 \\
Y.11 & 67,4286 & 315,134 &, 916 &, 987 \\
Y.12 & 67,4286 & 314,193 &, 870 &, 987 \\
Y.13 & 67,4857 & 313,551 &, 887 &, 987 \\
Y.14 & 67,5143 & 312,257 &, 911 &, 987 \\
Y.15 & 67,5143 & 310,551 &, 934 &, 987 \\
Y.16 & 67,5429 & 308,667 &, 931 &, 987 \\
Y.17 & 67,4571 & 309,079 &, 928 &, 987 \\
Y.18 & 67,6286 & 310,123 &, 933 &, 987 \\
\hline
\end{tabular}

\section{2) Uji Realibilitas}

Realibilitas adalah alat untuk mengukur suatu kuisioner yang merupakan indicator dari variabel atau konstruk. Suatu kuisioner dikatakan reliable atau andal jika jawaban seseorang terhadap pertanyaan adalah konsisten atau stabil dari waktu ke waktu. Uji realibiltas dilakukan dengan menggunakan uji statistic crobach alpha di mana suatu variabel dikatakan reliable jika nilai crobach alpha lebih dari 0,60 . Hasil uji realibilitas dalam penelitian ini adalah 


\section{Uji Realibilitas}

\begin{tabular}{|r|r|}
\hline $\begin{array}{c}\text { Cronbach's } \\
\text { Alpha }\end{array}$ & $\begin{array}{c}\text { N of } \\
\text { Items }\end{array}$ \\
\hline, 988 & 18 \\
\hline
\end{tabular}

\section{Pengujian Asumsi Klasik}

a. Uji Normalitas yaitu suatu pengujian yang bertujuan untuk menguji apakah dalam model regresi, variabel pengganggu atau residual memiliki distribusi normal (Gozali, 2013). Residual model regresi yang baik adalah memiliki distribusi residual yang normal atau mendekati normal. Hasil uji normalitas dalam penelitian ini

\section{One-Sample Kolmogorov-Smirnov Test}

\begin{tabular}{|ll|r|}
\hline & & $\begin{array}{r}\text { Unstandardi } \\
\text { zed Residual }\end{array}$ \\
\hline $\mathrm{N}$ & & 35 \\
Normal Parameters & Mean &, 0000000 \\
& Std. & 8,20155181 \\
\cline { 2 - 3 } & Deviation &, 119 \\
\cline { 2 - 3 } Most Extreme & Absolute &, 119 \\
\cline { 2 - 3 } & Positive &,- 098 \\
Test Statistic & Negative &, 119 \\
Asymp. Sig. (2-tailed) & &, $200^{c, d}$ \\
\hline
\end{tabular}

Dari data di atas maka diketahu nilai $A s y m p$. Sig (2 tailed) pada model persamaan regresi mempunyai nilai yang lebih besar daro 0,05 . Jadi dapat disimpulkan bahwa model persamaaan regresi tersebut telah memenuhi asumsi normalitas data. 
2. Uji multikolinearitas bertujuan untuk bertujuan untuk menguji apakah dalam model regresi ditemukan adanya korelasi antar variabel independen. Hasil uji multikolineartas dalam penelitian ini adalah

Coefficients ${ }^{a}$

\begin{tabular}{|ll|r|r|}
\hline \multirow{2}{*}{} & \multicolumn{2}{c|}{$\begin{array}{c}\text { Collinearity } \\
\text { Statistics }\end{array}$} \\
\cline { 2 - 4 } Model & \multicolumn{2}{|c|}{$\begin{array}{c}\text { Toleranc } \\
\mathrm{e}\end{array}$} & \multicolumn{1}{c|}{ VIF } \\
\hline $1 \quad$ Ukuran Koperasi &, 779 & 1,283 \\
& Jenis Koperasi &, 406 & 2,463 \\
\cline { 2 - 4 } & Pengalaman & & \\
& Kepengurusan &, 369 & 2,709 \\
& Manajemen & & \\
\hline
\end{tabular}

a. Dependent Variable: Kualitas SPI

Berdasarkan hasil analisis di atas dapat dilihat maka model regresi yang dipergunakan dalam penelitian ini tidak terdapat masalah multikolinearitas. Hal tersebut ditunjukkan dengan adanya nilai tolerance di antara variabel-variabel independen yang lebih besar dari 0,10 dan nilai VIF yang lebih kecil dari 10.

3. Uji heteroskedastisitas uji ini dimaksudkan untuk menguji apakah dalam model regresi terjadi ketidaksamaan variance dari residual satu pengamatan ke pengamatan yang lain. Model regresi yang baik adalah jika variance dari residual satu pengamatan ke pengamatan lain tetap atau homokedastisitas. 


\section{Coefficients ${ }^{\mathrm{a}}$}

\begin{tabular}{|c|c|c|c|c|c|c|}
\hline \multirow{2}{*}{\multicolumn{2}{|c|}{ Model }} & \multicolumn{2}{|c|}{$\begin{array}{c}\text { Unstandardized } \\
\text { Coefficients }\end{array}$} & \multirow{2}{*}{\begin{tabular}{|c|}
$\begin{array}{c}\text { Standardized } \\
\text { Coefficients }\end{array}$ \\
Beta \\
\end{tabular}} & \multirow[b]{2}{*}{$\mathrm{t}$} & \multirow[b]{2}{*}{ Sig. } \\
\hline & & $\mathrm{B}$ & Std. Error & & & \\
\hline \multirow[t]{4}{*}{1} & (Constant) & 4,935 & 4,146 & & 1,190 & ,243 \\
\hline & Ukuran Koperasi & $-1,670$ & 1,498 &,- 217 & $-1,115$ & ,273 \\
\hline & Jenis Koperasi &,- 282 & 2,086 &,- 036 &,- 135 &, 893 \\
\hline & $\begin{array}{l}\text { Pengalaman } \\
\text { Kepengurusan } \\
\text { Manajemen }\end{array}$ & 2,423 & 1,955 & ,350 & 1,239 & 225 \\
\hline
\end{tabular}

a. Dependent Variable: Absolut Residual

Berdasarkan hasil analisis di atas maka uji Gejser mengindikasikan bilai probabilitassignifikansinya berada di atas tingkat kepercayaan $5 \%(0,05)$ yang berarti dapat disimpulkan bahwa variabel-variabel independen dalam penelitian tidak mengandung gejala heteroskedastisitas.

\section{Analisis Regresi Linear Berganda}

Analisis regresi linear berganda digunakandalam penelitian ini untuk menguji lebi dari satu araibel independen terhadap satu variabel dependen. Hasil analisis uji regresi linear berganda dalam penelitian ini. 


\section{Coefficients ${ }^{\mathbf{a}}$}

\begin{tabular}{|c|c|c|c|c|c|c|}
\hline \multirow{2}{*}{\multicolumn{2}{|c|}{ Model }} & \multicolumn{2}{|c|}{$\begin{array}{c}\text { Unstandardiz } \\
\text { ed } \\
\text { Coefficients }\end{array}$} & \multirow{2}{*}{$\begin{array}{c}\begin{array}{c}\text { Standardized } \\
\text { Coefficients }\end{array} \\
\text { Beta }\end{array}$} & \multirow[b]{2}{*}{$\mathrm{t}$} & \multirow[b]{2}{*}{ Sig. } \\
\hline & & B & $\begin{array}{l}\text { Std. } \\
\text { Error }\end{array}$ & & & \\
\hline \multirow[t]{4}{*}{1} & (Constant) & $9,-$ & 6,582 & & $-1,463$ & , 153 \\
\hline & Ukuran Koperasi & 7,836 & 2,378 & ,336 & 3,295 &, 002 \\
\hline & $\begin{array}{l}\text { Jenis Koperasi } \\
\text { Penqalaman }\end{array}$ & 7,930 & 3,312 & ,338 & 2,395 & ,023 \\
\hline & $\begin{array}{l}\text { Kepengurusan } \\
\text { Manajemen }\end{array}$ & 7,617 & 3,104 & ,363 & 2,454 & ,020 \\
\hline
\end{tabular}

a. Dependent Variable: Kualitas SPI

Berdasarkan data dia tas, maka persamaan analisis regresi linear bergandanya adalah sebagai berikut:

$Y=-9,631+7,836 X_{1}+7,930 X_{2}+7,617 X_{3}$

Uji hipotesis 1 menyatakan bahwa ukuran koperasi berpengaruh terhadap kualitas sistem pengendalian intern, Hipotesis 2 menyatakan bahwa jeniskoperasi berpengaruh terhadap kualitas sistem pengendalian intern, Hipotesis 3 menyatakan bahwa pengalaman kepengurusan manajemen berpengaruh terhadap kualitas sistem pengendalian intern.

- Nilai signifikansi (p-value) varaiabel ukuran koperasi sebesar 0,002 $(<5 \%)$ yang berarti tingkat keyakinan bahwa ukuran koperasi berpengaruh terhadap kualitas sistem pengendalian intern $>95 \%$. Dengan demikian hipotesis yang menyetakan bahwa ukuran koperasi 
berpengaruh terhadap kualitas sistem pengendalian intern dapat diterima. Hal ini sejalan dengan penelitian yang dilakukan oleh Herawati yang menyatakan bahwa adanya perbedaan kualitas sistem pengendalian intern dari ukuran koperasi sehingga dapat dikatakan bahwa kualitas sistem pengendalian intern yang diterapkan oleh koperasi kecil, menengah, maupun besar berbeda. Semakin besar modal, omzet dan asset koperasimaka sistem pengendalian internnya semaikin baik.

- Nilai signifikansi (p-value) varaiabel jenis koperasi sebesar 0,023 $(<5 \%)$ yang berarti tingkat keyakinan bahwa jenis koperasi berpengaruh terhadap kualitas sistem pengendalian intern $>95 \%$. Dengan demikian hipotesis yang menyetakan bahwa jenis koperasi berpengaruh terhadap kualitas sistem pengendalian intern dapat diterima. Hal ini sejalan dengan penelitian yang dlakukan oleh Herawati (2013) yang menyatakan bahwa jenis koperasi berpengaruh terhadap kualitas sistem pengendalian intern.

- Nilai signifikansi ( $p$-value) varaiabel pengalaman kepengurusan manajemen sebesar 0,020 $(<5 \%)$ yang berate tingkat keyakinan bahwa pengalaman kepengurusan manajemen berpengaruh terhadap kualitas sistem pengendalian intern $>95 \%$. Dengan demikian hipotesis yang 
menyetakan bahwa pengalaman kepengurusan manajemen berpengaruh terhadap kualitas sistem pengendalian intern dapat diterima. Hal ini sejalan dengan hasil penelitian yang dilakukan oleh Herman (2012) yang menunjukkan bahwa pengalaman kerja pengewas berpengaruh terhadap efektifitas penerapan sistem pengendalian internnnya. Ini karena semakin berpengalaman pengawas akan mampu bekerja lebih teliti dan mampu mengetahui penyimpanganpenyimpangan yang terjadi dengan cepat dan disiplin waktu serta semakin berpengalaman pengawas intern koperasi maka semakin mampu menghasilkan kinerja yang lebih baik dalam tugas-tugasnya yang semakin kompleks, termasuk dalam melakukan pengawasan dan pemeriksaan terhadap penerapan struktur pengendalian intern koperasi.

\section{KESIMPULAN, KETERBATASAN, DAN SARAN}

Berdasarkan rumusan masalah, landasan teori, hipotesis dan hasil penelitian, maka dapat disimpulkan sebagai berikut:

1. Ukuran koperasi berpengaruh positif terhadap kualitas sistem pengedalian intern. Hasil Uji hipotesis 1 menyebutkan bahwa H1 dapat diterima yaitu 
ukuran koperasi berpengaruh positif terhadap kualitas sistem pengendalian intern.

2. Hasil Uji hipotesis 2 menyebutkan bahwa $\mathrm{H} 2$ dapat diterima yaitu jenis koperasi berpengaruh positif terhadap kualitas sistem pengendalian intern.

3. Hasil Uji hipotesis 3 menyebutkan bahwa $\mathrm{H} 3$ dapat diterima yaitu pengalaman kepengurusan manajemen berpengaruh terhadap kualitas sistem pengendalian intern.

Penelitian ini memiliki beberapa keterbatasan yaitu 1) hasil penelitian ini tidak dapat digeneralisasi karena penggunaan sampel yang terbatas yaitu hanya 35 koperasi yang ada di Kabupaten Tabanan, 2) Penelitian ini hanya menguji sistem pengendalian intern di Kabupaten Tabanan.

Penelitian selanjutnya disarankan dapat mengembangkan model dengan mencari faktor-faktor lain yang dianggap penting untuk analisis yang merupakan salah satu factor determinasi potensial yang mempengaruhi kualitas istem pengendalian intern seperti tingkat pendidikan karyawan dan lain-lain. Penelitian juga diharapkan dapat melakukan penelitian pada koperasi di kabupaten lainnya sehingga dapat membandingkan hasil yang diperoleh. 


\section{DAFTAR PUSTAKA}

Djohan, Djabaruddin, 2011, Wajah Koperasi Indonesia. Jakarta : Lembaga Studi Pengembangan Perkoperasian Indonesia (LSP21), Induk Koperasi Kredit (Inkopedit).

Ghozali, Imam, 2016, Aplikasi Analisis Multivariate dengan SPSS 20. Semarang: Badan Penerbit Universitas Diponogoro.

Halim, Abdul dan Totok Budi Santoso, 2004, auditing 2, Dasar-dasar Prosedur Pengauditan Laporan Keuangan Edisi Ketiga. Yogyakarta : Akademi Manajmen YKPN.

Haryono, AL, 2001, Auditing Cetakan Pertama. Yogyakarta: Sekolah Tinggi Ilmu Ekonomi YKPN.

Hasnawati, Novrina, 2012, Pengaruh Ukuran Koperasi dan Jenis Koperasi Terhadap Kualitas Sistem Pengendalian Intern, Diponegoro Journal Of Accounting Volume 1, Nomor 2 Tahun 2012, Universitas Dipenogoro. http:ejournalsl.undip.ac.id/index.php/accounting. Diakses pada tanggal 05 Nopember 2013.

Palupi, Astri Ken. 2011, Pengaruh Ukuran Koperasi dan Jenis Koperasi Terhadap Kualitas Sistem Pengendalian Intern. Skripsi Jurusan Ekonomi Undip. Semarang. 
Ni Made Intan P., Ni Made Rai I., \& Ni Putu Sri M. : Pengaruh Ukuran Koperasi, Jenis Koperasi ...

Mardiasmo, 2013, Standar Akuntansi Keuangan Entitas Tanpa Akuntanbilitas Publik. Jakarta : Ikatan Akuntansi Indonesia

Mulyadi, 2002, Accounting Auditing 1 edisi 6, Jakarta : Salemba Empat

Republik Indonesia, Undang-undang Nomor 25 Tahun 1992 Tentang Perkoperasian.

Republik Indonesia, Undang-undang Nomor 17 Tahun 2012 Tentang Perkoperasian, Sinar Grafika

Sudarsono, Edilius, 2005, Koperasi dalam Teori dan Praktek. Jakarta: Rineka Cipta

Sugiyono, 2013, Metode Penelitian Bisnis Cetakan ke-17. Bandung: CV Afabeta. Widiyati, Ninik, 2012, Manajemen Koperasi. Jakarta: Rineka Cipta.

Nita,Riana. 2011. "Pengaruh Pengendalian Intern Kas Terhadap Realisasi Pencatatan Penerimaan Kas". Skripsi Undiksa.

Rinawati, Anita. 2007. "Pengaruh Pendidikan Perkoperasian Anggota, Permodalan dan Pengalaman Pengurus Terhadap Keberhasilan Usaha Koperasi". Universitas Muhammadiyah Purweroje. Ejurnal.impwr.ac.id 